\title{
Evaluation of heavy metal concentrations in Rutilus frisii kutum on the southern coast of the Caspian Sea (northern Iran)
}

\author{
Dariush Naghipour ${ }^{1}$, Zeinab Shaabaninezhad ${ }^{2}$, Abdoliman Amouei ${ }^{3 *}$ \\ ${ }^{1}$ Assistant Professor of Environmental Health Engineering, Department of Environmental Health Engineering, School of Health, Guilan \\ University of Medical Sciences, Rasht, Iran \\ ${ }^{2} \mathrm{MSc}$ of Environmental Health Engineering, Student Research Committee, School of Health, Guilan University of Medical Sciences, \\ Rasht, Iran \\ ${ }^{3}$ Associate Professor of Environmental Health Engineering, Department of Environmental Health Engineering, School of Health, Babol \\ University of Medical Sciences, Babol, Iran
}

\begin{abstract}
Background: Marine products, especially fish, play an increasingly significant role in human diets and health. This research evaluated the concentrations of cadmium, lead, chromium, and nickel in liver and muscle tissues of Rutilus frisii kutum along the Caspian Sea coasts of northern Iran.

Methods: Thirty samples of fishes were taken from five stations (Astara, Rezvanshahr, Anazali, Ramsar, and Tonekabon) during fishing season. An ICP-OES spectrophotometer was used to determine concentrations of the studied metals. Data was analyzed by SPSS 19 using descriptive statistical index, $t$ test, and analysis of variance (ANOVA) test; $P<0.05$ was considered significant.

Results: Mean concentrations of cadmium, lead, chromium and nickel in the livers were 0.06, 1.1, 2.1 and $1.5 \mu \mathrm{g} / \mathrm{g}$ respectively and in the muscles were $0.05,0.8,1.7$ and $1.1 \mu \mathrm{g} / \mathrm{g}$, respectively. In liver: cadmium= $0.01-0.13$; lead $=0.3-2.7$; chromium $=0.9-4.5 ;$ nickel $=0.1-2.8$. In muscle: cadmium $=0.01-0.08$; lead $=0.2$ 1.5 ; chromium $=0.7-2.7$; nickel $=0.5-1.5$. Mean contents of these heavy metals were higher in the liver than in muscle. The order of heavy metal concentrations in the liver and muscle tissues were: $\mathrm{Cr}>\mathrm{Ni}>\mathrm{Pb}>\mathrm{Cd}$. The results showed statistically significant differences in the concentrations of these metals in liver and muscle tissues $(P<0.05)$, but no significant difference was observed between males and females.

Conclusion: Based on calculations, the estimated permissible tolerable weekly intakes (PTWIs) of cadmium $(0.042$ and $0.567 \mathrm{mg})$ and lead $(0.0021$ and $0.027 \mathrm{mg})$ in this study are lower than the levels established by the World Health Organization (WHO) ( $0.455 \mathrm{mg}$ for cadmium and $1.625 \mathrm{mg}$ for lead). Keywords: Heavy metals, Rutilus frisii kutum, Caspian Sea

Citation: Naghipour D, Shaabaninezhad Z, Amouei AI. Evaluation of heavy metal concentrations in Rutilus frisii kutum on the southern coast of the Caspian Sea (northern Iran). Environmental Health Engineering and Management Journal 2016; 3(2): 55-59. doi: 10.15171/EHEM.2016.01.
\end{abstract}

Article History:

Received: 2 January 2016 Accepted: 17 April 2016 ePublished: 26 April 2016

\section{Introduction}

The Caspian Sea is located in the northern part of Iran and has an area of $378400 \mathrm{~km}^{2}$ and a basin volume of 78170 $\mathrm{km}^{3}$. Its average and maximum depths are $210 \mathrm{~m}$ and 1025 $\mathrm{m}$, respectively (1).

Heavy metals in organic and inorganic compounds that are released into aquatic ecosystems are very dangerous because of their various toxicity levels and potential bioaccumulation in aquatic species (2,3). Unlike other pollutants, heavy metals are not degraded and eliminated by biological processes in the environment (2). Heavy metals can accumulate in different organs of fish through food and water $(4,5)$, and their contamination of aquacultures can be proven in water, sediments, and organisms (6). Heavy metal contents in different tissues of fishes are determined by their concentrations in water and food, and therefore can serve as a pollution bioindicator of aquatic ecosystems $(7,8)$. Fish have been widely used in assessing the quality of aquatic environments. These organisms are often at the top of the aquatic food chain and may accumulate large amounts of heavy metals from the surrounding waters $(9,10)$.

Cadmium, one of the most toxic heavy metals, is carcinogenic and has a long half-life (10-15 years), which leads to its gradual accumulation in the human body (6). Lead usually disrupts blood-forming and the nervous and reproductive systems $(7,8)$. Chromium causes dermatitis and irritates peripheral membranes $(1,4)$. Nickel is widely used in industry and is a common aquatic pollutant (5). In aquatic systems, nickel interacts with numerous inorganic and organic compounds and occurs as a soluble salt adsorbed into substances of different chemical origins (4). Other studies have detected the levels of some heavy metals in water, sediments, and several organs of fish. 
Rajkowska and Protosowicki assessed heavy metals accumulation in aquacultures consumed by humans and its effect on human health (3). Hassanpour et al determined the maximum concentrations of lead in water and sediments were 0.154 and $2.04 \mathrm{mg} / \mathrm{kg}$ and in the liver and kidney of wild birds (the common coot) were 1.2 and $2.1 \mathrm{mg} /$ $\mathrm{kg}$, respectively (11). Other investigations measured the accumulation of heavy metals in different tissues of fish, birds, and other aquacultures in the Caspian Sea. Najm et al found the concentrations of lead and chromium in the tissues of Clupeonella cultriventris and Gasterosteus aculeatus from the southern coast of the Caspian Sea to be less; however, the concentration of cadmium was higher than the recommended consumption limit for human health (12). Rajkowska and Protosowicki studied heavy metals accumulation ( $\mathrm{Fe}, \mathrm{Mn}, \mathrm{Zn}$, and $\mathrm{Cu}$ ) in different tissues of fish in two lakes of northern Poland (3). They suggested that the lowest levels of the studied metals were always detectable in muscle. The highest accumulations were $\mathrm{Mn}$ in the skin, gills, and gonads; $\mathrm{Zn}$ in the digestive tract and gills; and $\mathrm{Cu}$ in the liver. Nasrollahzadeh et al studied heavy metal $(\mathrm{Ni}, \mathrm{Cd}, \mathrm{Pb}$, and $\mathrm{Hg}$ ) contents in the edible tissue of Cyprinus carpio (13). They showed that $\mathrm{Ni}$, $\mathrm{Cd}$, and $\mathrm{Pb}$ contents in the muscle of this fish were lower than standard levels; however, the concentration of $\mathrm{Hg}$ was higher than the standard levels recommended by the World Health Organization (WHO) and Food and Agriculture Organization (FAO). Khoshnoud et al investigated the concentrations of metals $(\mathrm{Zn}, \mathrm{Cu}, \mathrm{Pb}, \mathrm{Cd}$, and $\mathrm{Hg}$ ) in two commercial fish species of the Persian Gulf (14). They stated that the concentrations of all metals had mean values lower than permissible limits set by WHO and FAO. Malakootian et al determined the concentrations of $\mathrm{Pb}$, $\mathrm{Cd}, \mathrm{Ni}$, and $\mathrm{Zn}$ in canned fish in southern Iran. Their results indicated that the concentrations of these toxic metals in tuna fish produced and marketed in Iran were much lower than the standard levels set by FAO and WHO (15). Considering the economic and nutritional values of white fish (Rutilus frisii kutum) from the Caspian Sea and the adverse effects of heavy metals on water quality and the health of fish, this study aimed to determine the concentrations of cadmium, lead, chromium, and nickel in the muscle and liver of fish in five fishing center stations on the southern coast of the Caspian Sea.

\section{Methods}

Description of the study area

The studied area included the southern coast of the Caspian Sea between Astara and Tonekabon located in Guilan and Mazandaran provinces. This area is located between longitudes $48^{\circ} 52^{\prime}$ and $50^{\circ} 57^{\prime}$ and latitudes $38^{\circ} 26^{\prime}$ and $36^{\circ} 52^{\prime}$ (Figure 1). The major rivers of this area, Sefid Rud, Cheshmeh Khileh, Pol Rud, Astara Chai, Chelvand, Garakan Rud, Kia Rud, Shalman Rud, Langrud Khan, and Masouleh Rud Khan, flow into the Caspian Sea.

\section{Sample preparation}

Thirty fish samples were collected from five fishery sta-

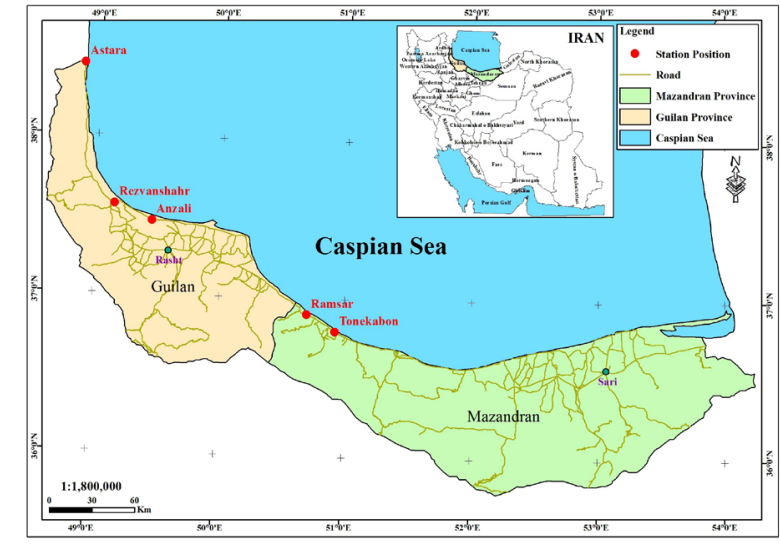

Figure 1. Location of the studied stations

tions from November 2013 to April 2014 (Figure 1). In the laboratory, the mass and total lengths of the fish were recorded. The fish were dissected and gender was determined by inspecting the gonads after the body cavity was opened. The muscles and liver were removed from each fish and preserved in the freezer $\left(-20^{\circ} \mathrm{C}\right)$ in clean, dry polyethylene bags. To prepare analytical samples, $1 \mathrm{~g}$ of the selected organ was weighed with an accuracy of 0.001 g. Hotplate digestion was performed using a mixture (7:3 v/v) of nitric acid (65\%, Merck, Germany) and perchloric acid (70\%, Merck, Germany). Then, the samples were dissolved in $5 \mathrm{~mL}$ of $15 \%$ nitric acid (9). At the end of the digestion stage, the samples were cooled and passed through Whatman filter paper 42. After that, $\mathrm{pH}$ values were reduced to below 2 using nitric acid, and volumes were increased to $25 \mathrm{ml}(16,17)$.

Determination of $\mathrm{Cd}, \mathrm{Pb}, \mathrm{Cr}$, and $\mathrm{Ni}$ contents

Concentrations of $\mathrm{Cd}, \mathrm{Pb}, \mathrm{Cr}$, and Ni were determined using inductively coupled plasma (ICP) optic emission spectrometry. Metal concentrations in tissues were expressed in micrograms per gram as wet weight. The wave lengths used for determining $\mathrm{Cd}, \mathrm{Pb}, \mathrm{Cr}$, and $\mathrm{Ni}$ were 228.8, 283.3, 267.7, and 231.6 nanometers, and detection limits were $0.05,2.1,0.1$, and $0.3 \mu \mathrm{grm} / \mathrm{l}$, respectively. After optimizing the ICP-OES device (Germany), its calibration curve was drawn using standard heavy metal levels to measure their concentrations in the prepared solutions.

\section{Statistical analysis}

All statistical analyses in this study were performed using SPSS version 19. The independent $t$ test was used to evaluate the statistical significance of differences in concentrations of heavy metals in fish based on gender. Analysis of variance (ANOVA) was used to identify significant differences in length and weight of fish, heavy metal contents in organs and gender by $t$ test. The level of significance was considered to be $95 \%$ and an error rate of less than $5 \%$ was acceptable $(P<0.05)$.

\section{Results}

Biometry study of the fish samples

In Table 1, the biometric characteristics of the fish samples 
are presented. The average length and weight of fish were higher at Anzali station than any other stations, but the difference was not statistically significant $(P>0.05)$.

\section{Heavy metal contents in fish organs}

The average concentrations of $\mathrm{Cd}, \mathrm{Pb}, \mathrm{Cr}$, and $\mathrm{Ni}$ in fish livers were $0.06 \pm 0.01,1.1 \pm 0.1,2.1 \pm 0.2$, and $1.5 \pm 0.1$ $\mu \mathrm{g} / \mathrm{g}$, respectively and in muscle were $0.05 \pm 0.01,0.8 \pm$ $0.1,1.7 \pm 0.2$, and $1.1 \pm 0.1 \mu \mathrm{g} / \mathrm{g}$, respectively (Figure 2 ). The mean content of all metals except cadmium was higher in the liver than in the muscle, and these differences were statistically significant $(P<0.05)$. The order of heavy metal concentrations in the muscle and liver of fish was $\mathrm{Cr}>\mathrm{Ni}>\mathrm{Pb}>\mathrm{Cd}$.

In Figure 3, the average concentrations of $\mathrm{Cd}, \mathrm{Pb}, \mathrm{Cr}$, and $\mathrm{Ni}$ in male and female fish are presented. According to this figure, the mean contents of all metals were higher in the tissue of female fish than male fish, but these differences were not statistically significant $(P>0.05)$.

Maximum and minimum $\mathrm{Cd}, \mathrm{Pb}, \mathrm{Cr}$, and $\mathrm{Ni}$ concentrations in the muscle of Caspian kutum were 0.08 and 0.01

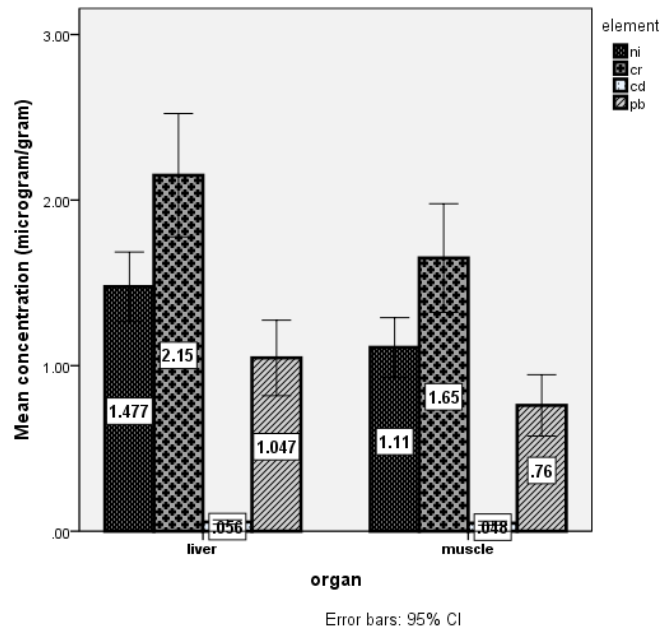

Figure 2. Mean heavy metal contents in liver and muscle tissues of Caspian kutum.

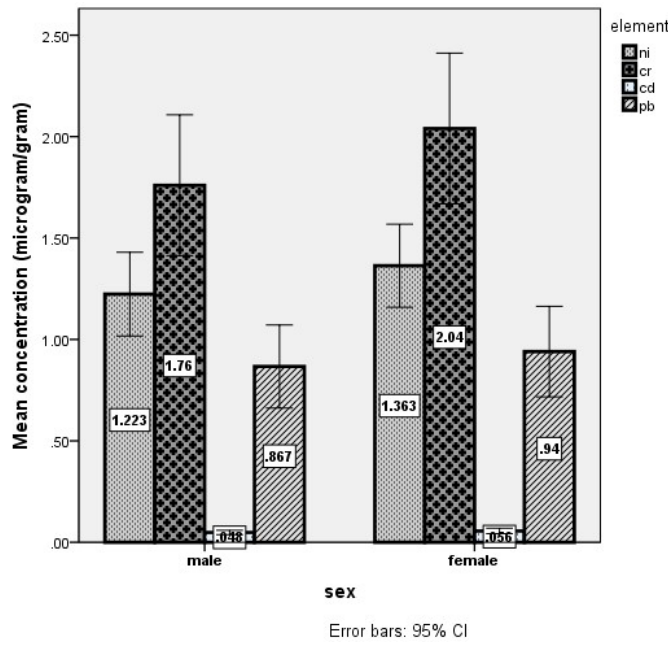

Figure 3. Mean heavy metal contents in male and female Caspian kutum. $\mu \mathrm{g} / \mathrm{g}, 1.5$ and $0.2 \mu \mathrm{g} / \mathrm{g}, 2.7$ and $0.7 \mu \mathrm{g} / \mathrm{g}, 1.5$ and $0.1 \mu \mathrm{g} / \mathrm{g}$, and in the livers, 0.13 and $0.01 \mu \mathrm{g} / \mathrm{g}, 2.7$ and $0.3 \mu \mathrm{g} / \mathrm{g}, 4.5$ and $0.9 \mu \mathrm{g} / \mathrm{g}$, and 2.8 and $0.1 \mu \mathrm{g} / \mathrm{g}$ as dry weight of the sample, respectively (Table 2 ). The $t$ test results showed that the differences in heavy metal concentrations in the muscle and liver of fish in the studied stations were statistically significant $(P<0.05)$.

\section{Discussion}

In the current study, the average length and weight of the fish was highest in Anzali station, but this difference was not statistically significant $(P>0.05)$. Moreover, there were no statistically significant differences between the heavy metals accumulation in liver and muscle and weight and length of the analyzed fishes $(P>0.05)$. Chakeri et al showed that there is no correlation between lead and cadmium contents in the muscle and liver of Rastrelliger kanagurta in the Persian Gulf and the size of the analyzed fish (18).

This study investigated the liver and muscle of fish because of their high nutritional value and importance in metabolism and the storage of chemicals $(17,19,20)$. The accumulation of lead, chromium, and nickel was higher in the liver of all fishes than in the muscle, and these differences were statistically significant $(P<0.05)$. The high contents of metal accumulation in the liver compared to the muscle of fish has been confirmed by other studies $(14,21)$. Elsagh investigated the bioaccumulation of heavy metals in the muscles of Rutilus kutum (17) and showed that the average concentrations of $\mathrm{Cd}, \mathrm{Pb}, \mathrm{Cr}$, and $\mathrm{Ni}$ in fish muscles were $2.6 \pm 1.3,1.2 \pm 0.3,0.65 \pm 0.12$ and $1.7 \pm$ $0.3 \mu \mathrm{g} / \mathrm{g}$, respectively. Furthermore, it was found that the mean accumulations of nickel and chromium in the muscle and liver of white fish along the coasts of the Caspian Sea were higher than those found in the Persian Gulf and along the coast of Bushehr. Yaghobzadeh et al determined that the mean accumulated concentrations of lead in kutum from the Bandar Anzali and Roodsar stations were $2.55 \pm 0.54$ and $1.66 \pm 0.25 \mu \mathrm{g} / \mathrm{g}$ dry weight, respectively (22). Results of the current study confirmed these investigations. In this study, the mean contents of all metals were higher in the tissue of female fish than male fish, but these differences were not statistically significant $(P>0.05)$. Turkmen et al found that in fish of the Aegean Sea, the accumulated contents of heavy metals were higher in the tissue of male fish than female fish (23). This result is not consistent with the results of this study. In the current study, the concentrations of all metals were higher in the analyzed fish from Bandar Anzali (station 3) than the other stations. The differences in mean contents of all metals in the liver and muscle between stations were statistically significant $(P<0.05)$. Studies have shown changes in the accumulation of metals in fish tissue may be caused by various factors such as type of metal, the target tissue or organ, gender, weight and age of fish, their feeding habits, duration of exposure to the metal, ecological features, environmental conditions, and physical and chemical properties of the environment $(17,23,24)$. 
Table 1. Weight and length (mean \pm SD) of Caspian kutum collected from the studied stations

\begin{tabular}{lllll}
\hline Station number & Station name & Sample number $(\mathbf{n})$ & Weight $(\mathrm{g})$ & Length $(\mathrm{cm})$ \\
\hline 1 & Astara $\left(\mathrm{S}_{1}\right)$ & 6 & $996.5 \pm 158.6$ & $40.7 \pm 6.3$ \\
2 & Rezvanshahr $\left(\mathrm{S}_{2}\right)$ & 6 & $1084.8 \pm 176.2$ & $43.4 \pm 7.8$ \\
3 & Anzali $\left(\mathrm{S}_{3}\right)$ & 6 & $1138.7 \pm 168.6$ & $48.2 \pm 6.8$ \\
4 & Ramsar $\left(\mathrm{S}_{4}\right)$ & 6 & $1112.2 \pm 165.5$ & $44.6 \pm 6.5$ \\
5 & Tonekabon $\left(\mathrm{S}_{5}\right)$ & 6 & $1025.4 \pm 182.5$ & $42.8 \pm 7.4$ \\
\hline
\end{tabular}

Table 2. Concentrations of metals as $\mu \mathrm{g} / \mathrm{g}$ (dry weight) in selected organs of Caspian kutum from different stations

\begin{tabular}{|c|c|c|c|c|c|c|c|c|c|c|c|c|c|c|c|c|}
\hline \multirow{3}{*}{ Station } & \multicolumn{4}{|c|}{ Nickel } & \multicolumn{4}{|c|}{ Chromium } & \multicolumn{4}{|c|}{ Cadmium } & \multicolumn{4}{|c|}{ Lead } \\
\hline & \multicolumn{2}{|c|}{ Liver } & \multicolumn{2}{|c|}{ Muscle } & \multicolumn{2}{|c|}{ Liver } & \multicolumn{2}{|c|}{ Muscle } & \multicolumn{2}{|c|}{ Liver } & \multicolumn{2}{|c|}{ Muscle } & \multicolumn{2}{|c|}{ Liver } & \multicolumn{2}{|c|}{ Muscle } \\
\hline & Min & Max & Min & Max & Min & Max & Min & Max & Min & Max & Min & Max & Min & Max & Min & Max \\
\hline$S_{1}(n=6)$ & 0.1 & 2.3 & 0.7 & 1.4 & 1.5 & 3.2 & 0.9 & 1.9 & 0.05 & 0.1 & 0.03 & 0.07 & 0.8 & 1.9 & 0.5 & 1.1 \\
\hline$S_{2}(n=6)$ & 0.7 & 1.6 & 0.5 & 0.9 & 0.9 & 2.2 & 0.7 & 1.4 & 0.01 & 0.03 & 0.01 & 0.02 & 0.3 & 1.1 & 0.2 & 0.6 \\
\hline$S_{3}(n=6)$ & 1.4 & 2.8 & 0.9 & 1.5 & 2.3 & 4.5 & 1.4 & 2.7 & 0.06 & 0.13 & 0.04 & 0.08 & 1.3 & 2.7 & 0.8 & 1.5 \\
\hline$S_{4}(n=6)$ & 0.9 & 1.8 & 0.6 & 1.2 & 1.2 & 2 & 0.8 & 1.5 & 0.04 & 0.09 & 0.03 & 0.05 & 0.5 & 1.3 & 0.3 & 0.8 \\
\hline$S_{5}(n=6)$ & 0.8 & 1.4 & 0.5 & 0.8 & 1 & 2.4 & 0.7 & 1.4 & 0.03 & 0.05 & 0.02 & 0.04 & 0.3 & 1.2 & 0.2 & 0.7 \\
\hline Mean \pm SD & \multicolumn{2}{|c|}{$1.5 \pm 0.1$} & \multicolumn{2}{|c|}{$1.1 \pm 0.1$} & \multicolumn{2}{|c|}{$2.1 \pm 0.2$} & \multicolumn{2}{|c|}{$1.7 \pm 0.2$} & \multicolumn{2}{|c|}{$0.06 \pm 0.01$} & \multicolumn{2}{|c|}{$0.05 \pm 0.01$} & \multicolumn{2}{|c|}{$1.1 \pm 0.1$} & \multicolumn{2}{|c|}{$0.8 \pm 0.1$} \\
\hline$P$ value & \multicolumn{2}{|c|}{$P<0.05$} & \multicolumn{2}{|c|}{$P<0.05$} & \multicolumn{2}{|c|}{$P<0.05$} & \multicolumn{2}{|c|}{$P<0.05$} & \multicolumn{2}{|c|}{$P<0.05$} & \multicolumn{2}{|c|}{$P<0.05$} & \multicolumn{2}{|c|}{$P<0.05$} & \multicolumn{2}{|c|}{$P<0.05$} \\
\hline
\end{tabular}

The minimum and maximum cadmium and lead concentrations in analyzed fish were 0.01 and $0.13 \mu \mathrm{g} \cdot \mathrm{g}^{-1}$ and 0.2 and $2.7 \mu \mathrm{g} . \mathrm{g}^{-1}$, respectively. The joint FAO/WHO expert committee on food additives established the permissible tolerable weekly intake (PTWI) for cadmium as 0.007 and for lead as $0.025 \mathrm{mg}$ per $\mathrm{kg}^{-1}$ body weight per week (22), which are equivalent to 0.455 and $1.625 \mathrm{mg}$ per week, respectively, for a $65 \mathrm{~kg}$ adult. Using the average weekly fish consumption in Iran of $210 \mathrm{~g}$ per person (16) and the minimum and maximum cadmium and lead levels measured in fish by this study, the weekly intake was calculated to range from 0.0021 to $0.027 \mathrm{mg}$ of cadmium per person and 0.252 to $0.504 \mathrm{mg}$ of lead per person in the muscle and liver of fish. As can be seen, the estimated PTWI of cadmium (0.042 and $0.567 \mathrm{mg}$ ) and lead (0.0021 and $0.027 \mathrm{mg}$ ) in this study is below the established PTWI ( $0.455 \mathrm{mg}$ for cadmium and $1.625 \mathrm{mg}$ for lead). The minimum and maximum chromium and nickel concentrations were 0.7 and $4.5 \mu \mathrm{g} \cdot \mathrm{g}^{-1}$ and 0.1 and $2.8 \mu \mathrm{g} . \mathrm{g}^{-1}$, respectively. Although there was no information about maximum permissible chromium and nickel levels in fish tissue in Iranian standards, the maximum permissible chromium and nickel reported by FAO for fish is $1 \mu \mathrm{g} \cdot \mathrm{g}^{-1}(22)$.

The high accumulation of heavy metals in the tissue of the analyzed fish clearly shows the considerable amount of pollution with these elements in the Caspian Sea waters at the studied stations. The regions covered in this study are considered centers of agricultural production. Because of the density of cultivation of various crops, large quantities of chemical fertilizers, pesticides, fungicides, and herbicides are used. The increase in $\mathrm{Cd}, \mathrm{Pb}, \mathrm{Cr}$, and $\mathrm{Ni}$ concentrations in the tissue of the fish at Bandar Anzali (station 3) is related to the hydraulic and hydrodynamic flows of the Caspian Sea, heavy marine traffic, and industrial wastewaters discharge, especially wastewater from the electroplating industry (21).

Conclusion

This research evaluated the contents of $\mathrm{Cd}, \mathrm{Pb}, \mathrm{Cr}$, and $\mathrm{Ni}$ in the tissue of Caspian kutum in northern Iran. Mean concentrations of these heavy metals were higher in liver tissue than in muscle tissue. The order of heavy metal concentrations in the muscle and liver tissues of fish were $\mathrm{Cr}>\mathrm{Ni}>\mathrm{Pb}>\mathrm{Cd}$. The results indicated that there are statistically significant differences among the accumulation of these metals in the liver and muscle tissues, but there was no significant difference in heavy metal concentrations between male and female fish. Based on calculations, the estimated PTWIs of cadmium (0.042 and $0.567 \mathrm{mg}$ ) and lead $(0.0021$ and $0.027 \mathrm{mg})$ in this study are lower than the PTWI established by WHO $(0.455 \mathrm{mg}$ for cadmium and $1.625 \mathrm{mg}$ for lead).

\section{Acknowledgments}

The authors would like to thank Reyhaneh Barari for her English editing of the manuscript and the Chancellor of Research and Technology in Guilan University of Medical Sciences for financial support of this work.

\section{Ethical issues}

It is confirmed that this manuscript is the original work of the authors. It has not been published, nor is it under review in another journal, and it is not being submitted for publication elsewhere.

\section{Competing interests}

The authors declare that they have no competing interests.

\section{Authors' contribution}

All authors contributed equally and participated in the 
collection, analysis, and interpretation of the data. All authors critically reviewed, refined, and approved the manuscript.

\section{References}

1. Dumont HJ. The Caspian lake: history, biota, structure and function. Limnol Oceanogr 1998; 43(1): 44-52.

2. Birungi Z, Masola B, Zaranyika MF, Naigaga I, Marsall B. Active biomonitoring of trace heavy metals using fish (Oreochromis niloticus) as bioindicator species. The case of Nakivubo wetland along Lake Victoria. Physics and Chemistry of the Earth 2007; 32(15-18): 1350-8.

3. Rajkowska M, Protosowicki M. Distribution of metals (Fe, $\mathrm{Mn}, \mathrm{Zn}, \mathrm{Cu}$ ) in fish tissues in two lakes of different trophy in northern Poland. Environ Monit Assess 2013; 185(4): 3493-502.

4. Golovanova IL. Effect of heavy metals on the physiological and biochemical status of fishes and aquatic invertebrates. Inland Water Biology 2008; 1: 93.

5. Kraal MH, Kraak MH, De Groot CJ, Davids C. Uptak e and tissues distribution of dietary and aqueous cadmium by Carp (Cyprinus carpio). Ecotoxicol Environ Saf 1995;31(2): 179-83.

6. Moiseenko TI, Kurdyavtseva LP. Trace metal accumulation and fish pathologies in areas affected by mining and metallurgical enterprises in the Kola Region, Russia. Environ Pollut 2001; 114(2): 285-97.

7. Fan W, Wang WX, Chen J. Geochemistry of Cd, Cr and $\mathrm{Zn}$ in highly contaminated sediments and its influences on assimilation by marine bivalves. Environ Sci Technol 2002; 36(23): 5164-71.

8. Farkas A, Salanki J, Varanka I. Heavy metal concentrations in fish of Lake Balaton. Lakes Reservoirs: research and management 2000; 5: 271-9.

9. Protasowicki M. Sex effects on $\mathrm{Cd}, \mathrm{Pb}, \mathrm{Cu}$ and $\mathrm{Zn}$ contents in selected fish organs. Baltic Sea Environment Proceedings. 1986; 19: 433-41.

10. Ptashynski MD, Pedlar RM, Evans RE, Baron CL, Klaverkamp JF. Toxicology of dietary nickel in Lake Whitefish (Coregonus clupeaformis). Aquatic toxicology, 58 (3-4): 229-47.

11. Hassanpour M, Pourkhabbaz A, Ghorbani R. The measurement of heavy metals in water, sediments and wild bird (Comoon coot) from the southeast Caspian Sea. J Mazand Univ Med Sci 2012; 22 (suppl 1): 184- 94. [In Persian].

12. Najm M, Shokrzadeh M, Fakhar M, Sharif M, Hosseini SM, Rahimi-Esboei B, et al. Concentration of heavy metals $(\mathrm{Cd}, \mathrm{Cr}$, and $\mathrm{Pb})$ in the tissues of Clipeounella cultriventis and Gasterosteus aculeatus from Babolsar coastal waters of Mazandaran province, Caspian Sea. J Mazand Univ Med Sci 2014; 24(113): 185- 92. [In Persian].

13. Nasrollahzadeh Saravi H, Pourgholam R, Pourang N,
Rezaei M, Makhlough A, Unesipour H. Heavy metal concentrations in edible tissues of Cyprinus carpio and its Target Hazard Quotients in the southern Iranian Caspian Sea coast (2010). J Mazand Univ Med Sci 2013; 23(103): 3344. [In Persian]

14. Khoshnoud MJ, Mobini K, Javidnia K, Hoosseinkhezri $\mathrm{P}$, Aeen Jamshid Kh. Heavy metals $(\mathrm{Zn}, \mathrm{Cu}, \mathrm{Pb}, \mathrm{Cd}$, and $\mathrm{Hg}$ ) contents and fatty acid ratio in two fish species (Scomberomorus commerson and Otolithes ruber) of the Persian Gulf. Iranian Journal of Pharmaceutical Sciences 2011; 7(3): 191-6.

15. Malakootian $M$, Tahergorabi $M$, Daneshpajooh $M$, Amirtaheri K. Determination of $\mathrm{Pb}, \mathrm{Cd}, \mathrm{Ni}$ and $\mathrm{Zn}$ concentrations in canned fish in southern Iran. Sacha Journal of Environmental Studies 2011; 1(1): 94-100.

16. Agah H, Leermakers M, Elskens M, Fatemi SM, Baeyens W. Accumulation of trace metals in the muscle and liver tissues of five species from the Persian Gulf. Environ Monit Assess 2009; 157(1-4): 499-514.

17. Elsagh A. Bioaccumulation of heavy metals levels in muscles of Rutilus frisii kutum and Cyprinus carpio Fishes of coastal waters of the Mazandaran Province, Caspian Sea. Quarterly Veterinary Journal (Pajouhesh-va-Sazandegi) 2012; 95(2): 41-8. [In Persian].

18. Chakeri R, Sajadi MM, Kamrani E, Aghajari N Determination of heavy metal (lead and cadmium) concentrations in liver and muscle tissue of Indian mackerel (Rastrelliiger kanagurta) in Persian gulf. Iranian Scientific Fisheries Journal 2015; 24(2): 115-25.

19. Filazi A, Baskaya R, Kum C, Hismiogullari SE. Metal concentration in tissues of the Black Sea fish (Mugil auratus) from Sinop-Icliman, Turkey. Hum Exp Toxicol 2003; 22(2): 85-7.

20. Amini Ranjbar G, Sotodehnia F. Investigation of heavy metals accumulation in muscle tissue of mugil auratus in relation to standard length, weight, age and sex). Iranian Fisheries Scientific Journal. 2005; 16( 3): 1-19.

21. Uluozlu OD, Tuzen M, Mendil D, Soylak M. Trace metal content in nine species of fish from the Black and Agean seas, Turkey. Food Chem 2007; 104(2): 835-40.

22. Yaghobzadeh Y, Hossein-Nezhad M, Asadi-Shiran G, Pourali M. An investigation of Lead concentration in Rutilus frisii kutum from Caspian Sea: Case study of Bandar Anzali and Roodsar, Iran. J Mazand Univ Med Sci 2014; 23(110): 102-8. [In Persian].

23. Turkmen M, Turkmen A, Tepe Y. Metal concentrations in five fish species from Black, Marmara, Agean and Mediterranean seas, Turkey. J Chil Chem Soc 2008; 53(1): 1435-39.

24. Tepe Y, Turkmen M, Turkmen A. Assessment of heavy metals in two commercial fish species of four Turkish seas. Environ Monit Assess. 2008; 146(1): 277-84. 